\title{
A STUDY ON SPEECH INTELLIGIBILITY IN PATIENTS WITH PARALYTIC DYSARTHRIA FOLLOWING CEREBRAL APOPLEXY
}

\section{KIYOJI KANAI}

\author{
Department of Otorhinolaryngology Showa University, School of Medicine \\ (Director: M. Okamoto, M.D.)
}

The communicable abilities of patients with dysarthria following cerebral apoplexy were mostly represented by their speech intelligibility measured by articulation tests. The relationships between the speech intelligibility and the movement of paralytic articulatory organs were studied. The tendencies of misspeaking of apoplexic patients were analyzed by auditory and physical methods. Consequently, the incomplete postnasal obstruction method was taken up improve the speech intelligibility of the patients with paralytic dysarthria. The results obtained were as follows:

1. There were close relationships between the speech intelligibility and the paralytic movements of the articulatory organs of apoplexic patients.

2. The patients with mild paralytic articulation disorders had minor disorders of soft palatal sounds, but speech disorders in vocal frictional and explosive sounds were remarkable.

3. Regardless of the degree of articulation disorders, they had high speech intelligibility of vowels and glottal sounds.

4. The patients with serious paralytic articulation disorders misspoke characteristically. They had less misspeaking in the vowels which were the part of some syllables, but they had strong tendencies of misspeaking the consonants just like glottal sound and nasal sound. For example, in the sound of " $\mathrm{ka}$ ", they could correctly pronounce " $\mathrm{a}$ " part, but " $\mathrm{k}$ " sound was pronounced like "h" sound.

5. The analysis of misspeaking sounds by the sonagram showed the disappearance of spike fill of explossive consonants, but the remarkable increase in extraresonance and interflling due to nasalization of vowels was seen.

6. The speech of the patients with paralytic dysarthria who had not been treated successfully was improved by the incomplete postnasal obstruction method.

79A-0478. 10522

\section{脳卒中後の麻痺性構音障害患者の発語明瞭度について}

\author{
昭和大学医学部耳鼻咽喉科学教室（主任：岡本途也） \\ 金 井 清 次
}

\section{I. 序論}

人間は言葉によつて多くの情報を交換し，今日の文明 を筑いてきた。この言葉を発するということは，簡临な ことに思えるが，表現したい情報の概念を形成し，それ を言語中枢で言語学的構成に変化させ, 未梢構音器官を
作動させて発語するのであるから非常に複雑である。そ の表出言語は幾つかの要素を持つている，すなわち，表 現したい情報内容は吻論のこと,一つ一つの語音の特 徴，それらが配列される様式，発声される語音の抑愓， リズム, 速度, さらに住声の高さ, 強さ, 音質などがそ 
れである。ささらに表出された情報内容や音響学的音声言 語は，発語者の聴覚系を通じて発声発語する諸機構につ イードバックされ，そしてコントロールされているの で，表出言語は単に言語系のみの機能が関与して構成さ れるものではない。

このように複雑な機構により言語が表出されるのであ るからこれらの機構の中で，どこが障害されても言語 障害となりうる。

著者は脑卒中にともなつた言語障害例を多く診る機会 をえたが，これらの言語障害例は，失語症と麻㾝性構音 障害に大別される。しかしこれら障害例は老人が多く， 聴覚障害, 老人性痴呆が加わつている場合も多いその ため脑卒中後の言語障害の治療には多くの困難な問題が ある，そこで著者注脳卒中後の麻疩性構音障害について 種々倹討し，言語療法についても考案したので，その結 果を報告する。

\section{II. 研究対象}

太田総合病院附属熱海総合病院コミュニクーションク リニックにて言語訓練を受けている脳卒中後の麻瘦性構 音障害13例を研究対象とした。

年齢は32歳 77歳で，ほとんどの症例が50歳以上であ
る。その一覧表を表 1 に示す 各症例の順位(症例番号)

は，当クリニックのスピーチテラピストが被検者とコミ ュニクーションをとり，主観的に儇务の順位をつけたも のを採用した，すなかち，第 I 症例がもつともコミュニ ケーションをとりやすいものであり第XIII症例がもつと もとりにくいものである。

第四症例を例にとり，表 1 を説明する。

症例 II O崎○男 857 歳

款断 脳出血

主訴：右上下肢の麻瘦，言語障害

現病歷：昭和44年 7 月 24 日突然意識不明となり，右上 下肢の不全麻㾝が出現した．昭和46年 1 月 8 日再度発作 が起り，右上下肢の完全麻疩と言語障害が出現した。昭 和46年 7 月 4 日の所見では，右上下肢の麻痶があり異常 健反射もみられた，有杖歩行は可能であるが，右手によ る書字は不能であつた。

音声言語学的所見：喉頭運動怯正常で発声可能であつ た. 構音器官は軟口盍に軽度の運動障害を認め, 舌およ び口唇の運動は正常で，舌軟口蓋の協摆運動は良好であ つた，発語明睹度 $81 \%$ ，発声持続時間 17 秒，連続構音回 数 又15回，夕14回，力13回，パ17回/5秒，シュール笹

表 1 研 究 対 象

\begin{tabular}{|c|c|c|c|c|c|c|c|c|c|c|c|c|c|c|c|c|c|c|}
\hline \multirow{2}{*}{$\begin{array}{l}\text { 应 } \\
\text { 例 }\end{array}$} & \multirow{2}{*}{$\begin{array}{l}\text { 年 } \\
\text { 令 }\end{array}$} & \multirow{2}{*}{ 性 } & \multirow{2}{*}{ 病名 } & \multirow{2}{*}{ 麻㾖 } & \multirow{2}{*}{ 总語障害 } & \multirow{2}{*}{$\begin{array}{l}\text { 発 } \\
\text { 症 } \\
\text { 日 }\end{array}$} & \multirow{2}{*}{ 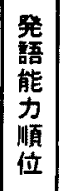 } & \multirow{2}{*}{ 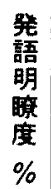 } & \multicolumn{4}{|c|}{$\begin{array}{r}\text { 連統䧿音回数 } \\
\text { 回数 } / 5 \text { 秒 }\end{array}$} & \multicolumn{3}{|c|}{$\begin{array}{r}\text { 䨀音器官 } \\
\text { 運款性 }\end{array}$} & \multirow{2}{*}{ 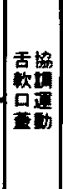 } & \multirow{2}{*}{\begin{tabular}{|l} 
発 \\
声 \\
絓 \\
堒 \\
間
\end{tabular}} & \multirow{2}{*}{$\begin{array}{l}\vec{J} \\
1 \\
\boldsymbol{x} \\
1 \\
Q\end{array}$} \\
\hline & & & & & & & & & २ & צ & カ & パ & $\begin{array}{l}\text { 軟 } \\
\text { 愠 }\end{array}$ & 舌 & $\begin{array}{l}\text { 口 } \\
\text { 晨 }\end{array}$ & & & \\
\hline 1 & 50 & $\delta$ & 脳血栓 & 右片麻瘨 & 㽽性楆音 & $\begin{array}{l}\text { 14年 } \\
6 \text { 月 }\end{array}$ & 1 & 83 & 18 & 18 & 16 & 19 & 1 & & 5 & 9 & 12 & 73 \\
\hline II & 5 & 今 & 敛出血 & 右片席疩 & 麻㽻性椿音 & $\begin{array}{l}44 \text { 年 } \\
\text { 7月 } \\
\end{array}$ & 2 & 81 & 15 & 14 & 13 & 17 & 4 & & 5 & 9 & 17 & 77 \\
\hline III & & 우 & 脳出血 & 右片麻㾕 & 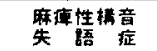 & $\begin{array}{l}\text { 40年 } \\
3 \text { 月 }\end{array}$ & 3 & 80 & 21 & 15 & 14 & 19 & 4 & & 4 & 8 & 8 & 53 \\
\hline IN & 57 & $\hat{o}$ & 畄出血 & 右片麻瘪 & 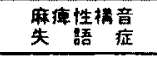 & $\begin{array}{l}37 \text { 年 } \\
\text { 12月 }\end{array}$ & 4 & 63 & 19 & 17 & 14. & 13 & 1 & & 4 & 5 & 11 & 68 \\
\hline$v$ & 57 & $\hat{o}$ & 睬血栓 & 右片麻瘦 & 麻瘦性椿音 & 10月 & 5 & 48 & 13 & 11 & 11 & 13 & 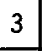 & & 3 & 7 & 5 & 71 \\
\hline 11 & 59 & 우 & 睬血栓 & 左片麻禅 & 麻痊性樓音 & $\begin{array}{r}47 \text { 年 } \\
1 \text { 月 }\end{array}$ & 6 & 41 & 19 & 16 & 14 & 13 & 2 & & 4 & 5 & 7 & 43 \\
\hline 17] & 77 & t & 䁘软化 & 右片麻㾝 & 麻㾝性構音 & $\begin{aligned} 47 \text { 年 } \\
2 \text { 月 }\end{aligned}$ & 7 & 40 & 20 & 19 & 20 & 21 & 2 & & 3 & 5 & 12 & 68 \\
\hline II & 60 & 우 & 脳软化 & 右片麻㾝 & 麻㾝性棒音 & $\begin{array}{r}45 \text { 年 } \\
4 \text { 月 }\end{array}$ & 8 & 33 & 9 & 12 & 9 & 9 & 1 & 3 & 1 & 4 & 6 & 77 \\
\hline $\mathrm{x}$ & 58 & $\hat{\delta}$ & 脳软化 & 右片麻㾝 & 麻痡性榙音 & 38月 & 9 & 32 & 12 & 8 & 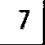 & 11 & 2 & & 3 & 4 & 6 & 60 \\
\hline$x$ & 67 & $\hat{\delta}$ & 脳血栓 & 左片麻㾝 & 麻疸性楅音 & $\begin{array}{l}\text { 39年 } \\
9 \text { 月 }\end{array}$ & 10 & 31 & 12 & 8 & 8 & 10 & 1 & & 4 & 4 & 11 & 76 \\
\hline $\mathrm{XJ}$ & 67 & $\hat{\delta}$ & 脳血拴 & 右片麻㾝 & 麻㾝性欈音 & $\begin{array}{l}\text { 46年 } \\
11 \text { 月 }\end{array}$ & 11 & 16 & 10 & 8 & 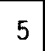 & 6 & 4 & 2 & 1 & 3 & 16 & 69 \\
\hline . & 59 & 우 & 脳出血 & 左片麻㿉 & 麻㾝性輠音 & $\begin{array}{l}\text { 38 } \\
\text { 8月 }\end{array}$ & 12 & 14 & 12 & 14 & 11 & 12 & 1 & 2 & 2 & 3 & 4 & 51 \\
\hline Xit & 50 & 오 & 岁软化 & 右片麻㾝 & 麻㾝性棰音 & $\begin{array}{l}\text { 45年 } \\
9 \text { 月 } \\
\end{array}$ & 13 & 9 & 18 & 14 & 12 & 13 & 1 & 5 & 4 & 3 & 20 & 80 \\
\hline
\end{tabular}


沼失語症簡易検查にて, 運動失語および感覚失語を認め なかつた。

心理学的所見 : Kohs I.Q. 77

以上の所見から, 脳出血後遣症による錐体路性麻㾝性 構音障害と診断した. 症例而のこれらの所見を表 1 に表 示したが, 他の症例も同様の方法で表 1 に示した。構音 器官の運動性の項については, 著者が全症例を診察し, 口唇の閉鎖力や, 舌の速やかな出し入れ, 左右運動, お よびまるめ運動, 軟口蓋の挙上運動を観察し，5段階法 を用いて評価した，すなわち，5：構音運動正常，4： やや運動障害あり，3：運動障害著明，2：構音運動を わずかに認める、1 1 : 全く運動せず，を基準に判定し た.この際, 舌と軟口蓋との協調運動を重視し, 両者の 点数の和をもつて軟口蓋協調運動評価とした，その他の 音声言語学的諸検查は, 日本音声言語医学会で常用され ている方法で，主として，切替 ${ }^{1}$, 田口年等の成書にした がつて行つた. 心理学的検查は S.C. Kohs による方法 で，驾，難聴，言語障害者を対象汇視賞を通じて知能指 数を推定する方法で, 70 以上が正常とされている.

\section{III. 研究方法}

(1) 発語明膫度の測定

測定に用いた語表は，日本語の清濁語音 67 個を無作意 に配列したものである(表 2 ). 正答率を計算する時, 検 者が検查語音を記憶してしまらことを避けるため, 語音 の配列順序の異なる数種の語表を用いた.

検查手順は, 被検者に検查語音を $2 \sim 3$ 秒間隔で発語 させ，至適条件にて録音した．使用したマイクロホンは ソニーECM-913,テープレコーダは TEAC A-7030GSL で, テープ速度は $19 \mathrm{~cm} /$ 秒である。

各症例の発語明膫度注後日, このテープを再生して測

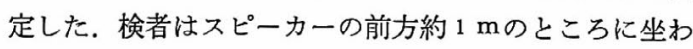

\begin{tabular}{|c|c|c|c|c|c|c|c|c|c|c|}
\hline & & & & & 語 & & 表 & & & \\
\hline & 1 & 2 & 3 & 4 & 5 & 6 & 7 & 8 & 9 & 10 \\
\hline & ぱ & $ぬ$ & よ & ご & ぜ & $め$ & べ & ざ & & ち \\
\hline & さ & 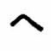 & כ & か & が & ば & S゙ & u & も & ふ \\
\hline & す & む & ね & お & せ & $<$ & $ゆ$ & 3 & こ & L \\
\hline & ぐ & ど & は & や & う & で & な & え & & に \\
\hline & わ & け & あ & ま & t & れ & い & 9 & そ & ペ \\
\hline & ぎ & ぞ & げ & $u^{\circ}$ & と & き & び & $2 x$ & & る \\
\hline & ぼ & 5 & ほ & $\tau$ & の & だ & ぷ & & & \\
\hline
\end{tabular}

り，再生された語音を必要充分な音の大きさに増幅して 聴取し，きこえたとおりを記載した．その結果と検查語 音を照合し，検者が正しく聴取した語数の百分率值を求 め,これをむつて被検者が発語した語音の正答率とし た. 検者 7 名の正答率の 5 最高值と最低值を除き, 残 り 5 名の正答率の算術平均をもつて被検者の発語明膫度 とした. ただし, 検者は聴力が正常であること, 被検者 の声に聞き慣れていないことおよび検者と, 被検者の方 言を考虑して被検者と同一地方の出身であることの条件 により選んだ。

(2)被検者の発声法

(a自然の状態での発声

(後鼻孔不完全開鎖法による発声

この方法はベロックタンポンに準じて行つた. すなわ ち, ベロックタンポンは鼻腔後部よりの鼻出血時に後鼻 孔を完全に閉鎖し，止血をこころみる方法であるが，こ の状態では後鼻孔を完全閉鎖して発語時の通鼻が不可能 になるため, $1 / 2$ 拇指頭大のガーゼ塊をたは, バルーン カテーテルを用い, 上咽頭に挿入し，その狭窄をはかつ た. すなわち軟口蓋およびパッサーバン隆起のわずかに 残つた運動により発語時に鼻咽腔の閉鎖できるよらにこ ころみた。（図 1)

\section{IV. 研究結果}

\section{A. 自然の状態での発語}

(1) 発語明瞭度

表 1 に各症例の発語明瞭度を記入した。発語明眿度は

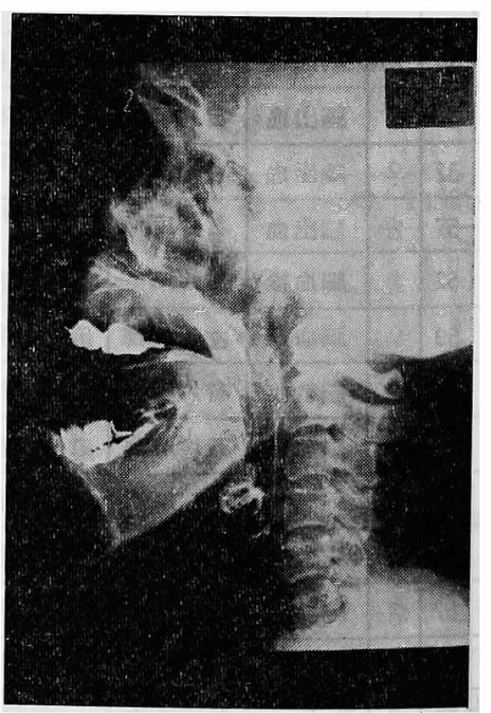

図 1 後鼻孔不完全鎖法施行時のレントゲン写真 


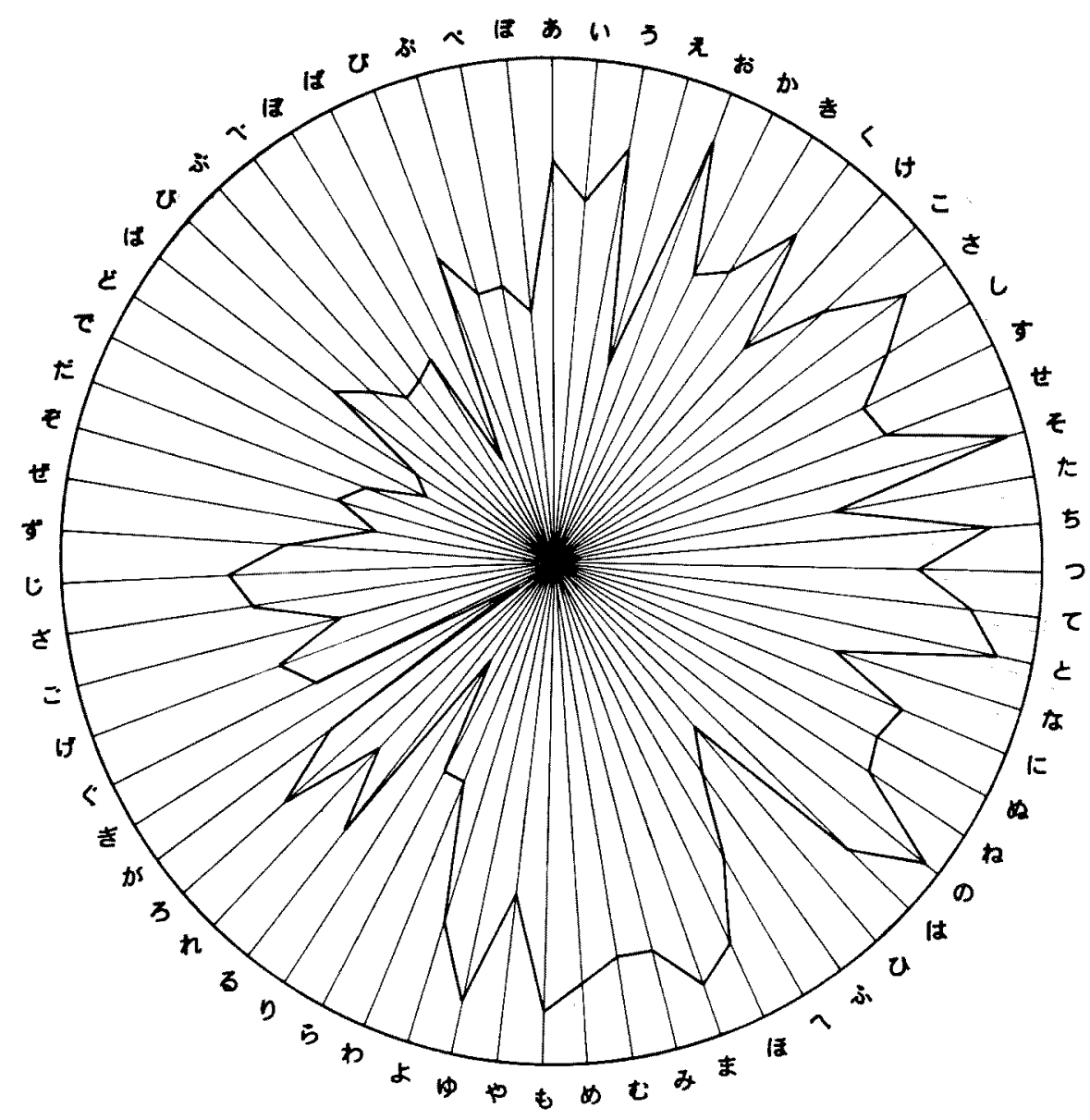

図 2 軽度構音障害患者（症例 I VII）の語音別発語明膫度

9 83\%まで広範に分散した。表 1 から症例番号にした がって発語明膫度は良くなつている。すなわちスピーチ テラピストの主観的な言語能力の判定に発語明膫度は直 接関保している. この5ち発語能力順位 7 までの 7 症 例, すなわち, 舌と軟口蓋協調運動評価 5 以上のものの 発铻明膫度は40\%以上であつた。

症例 I 〜 VII 語音別発語明膫度の総計の百分率を図 2 に示した。この図から明らかなように母音の発語明膫度 は良く，また，子音のなかで発語明膫度の良いのは， 「汃行,「さ」行,「た」行,「ま」行,「な」行である。 次に症例䜣 XIIの，発語能力の悪い，6症例，すなわ ち軟口蓋と舌の協調運動評価 4 以下のものの発語明膫度 は39\%以下であった．この症例证〜 XIIの語音別発語明瞭 度の総計の百分率を図 3 に示す，この図から明かなよ5
に，正常耳が聴取し弁別可能な語音は，母音と声門音， 通且音だけで，他の語音は聴取弁別不可能である。

(2) 発語の誤聴される傾向

被検者の表出語音恃，検者に母音，声門音，通鼻音に 誤つて聴取される一定の傾向があつた，先の結果を表 3

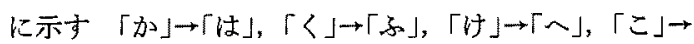

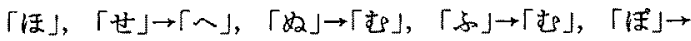

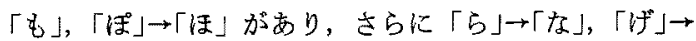

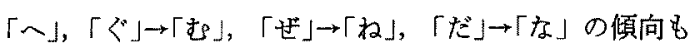
認められた，すなわち，脑卒中による麻㾝性構音障害の 発語は蔧音不充分であるのみならず，鼻音化される傾向 がある。

\section{B. 後鼻孔不完全閉鎖状態での発語}

この実験の対象者は各症例のうち発語明膫度 $40 \%$ 以下 


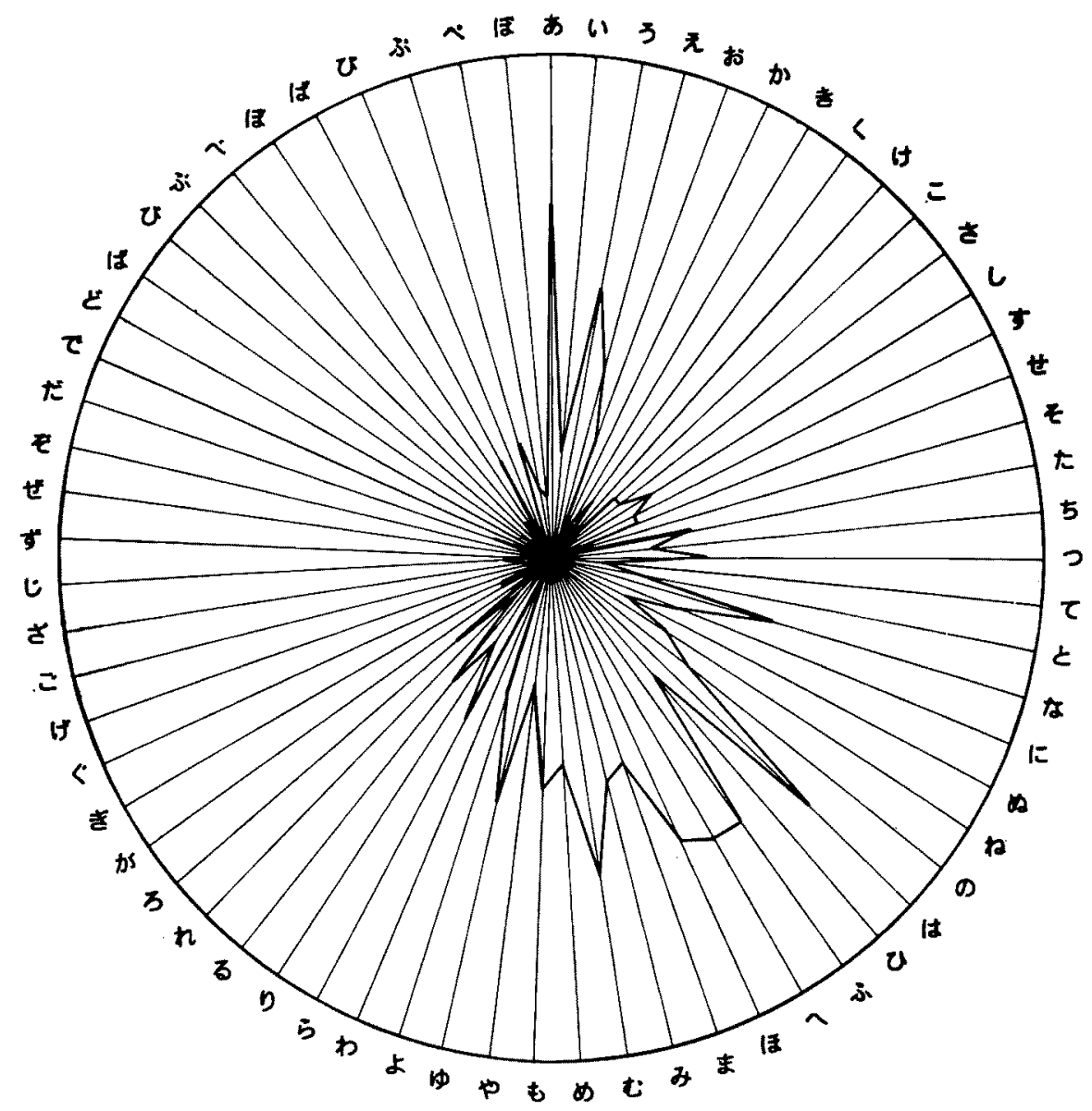

图 3 高度麻軒性構音障害患者（症例VII ～X目）の語音別発語明膫度

で，舌㜞口蓋協調運動評価 5 以下の 6 例（症例VII， IX,

$\mathrm{X}, \mathrm{IX}, \mathrm{XII}, \mathrm{XIII}$ ) である.

(1)発語明瞭度の変化

後鼻孔不完全閉鎖した時の発語明瞭度の変化を図 4 に 示寸.

これらの症例の自然の状態での発語明瞭度の平均は 22\%であつたが，後禀孔不完全閉鎖法を行らと発語明瞭 度は平均 $26 \%$ となた。すおわち，全体として，鼻咽腔 を狭窄にしても発語明瞭度の明らかな上昇は認められな かつた.しかし，図4から明らかなように症例IXでは，後 鼻孔を不完全閉鎖すれば著明に発語明睹度の上昇 (32\% $\rightarrow 49 \%$ ）をきたした.この症例は他の症例よりも舌運動 が軽度に諗められ，舌運動 3 ，軟口蓋運動 1 であつた。 その他の例では，症例XIIを除き，発語明瞭度は変化しな
いか，低下していた。

(2)語音別発語明瞭度の変化

後番孔を不完全闒鑟した場合の発語明膫度の変化を語

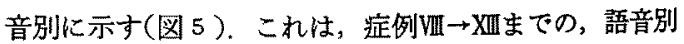
の正答率平均である。自然の状態と，後鼻孔不完全閉镍 した場合の発語を比較すると，各行において明らかな明 瞭度の変化を認めない，しかし語音別に見ると，「括」， 「て」，「ひ小、「わ」等は明らかに正答率の上昇を热めた が，逆に，明らかな正答率の低下をきたした語音はなが つた.

\section{C、誤聴されやすい語音のソナグラフによる分析}

方法：被検者の発語した語音と譟つて聴取された本人 の語音，括よび正常人の語音をリオンサウンドスペクト ルグラフ SG07 で分析し，比較検討した. 
表 3 麻淖性構音障害患者発語の誤聴される傾向

\begin{tabular}{|c|c|c|c|c|c|c|c|c|}
\hline \multirow{2}{*}{ か } & か & は & $x$ & \multirow{2}{*}{ こ } & \multirow[t]{2}{*}{$こ$} & \multirow{2}{*}{$\frac{ほ}{18}$} & \multirow{2}{*}{$\frac{\text { は }}{4}$} & \multirow{2}{*}{$\frac{x}{20}$} \\
\hline & 0 & 22 & 20 & & & & & \\
\hline \multirow{2}{*}{$<$} & $<$ & 心 & $x$ & \multirow{2}{*}{ ぶ } & ぶ & む & $x$ & \\
\hline & 0 & 27 & 15 & & 1 & 24 & 17 & \\
\hline \multirow{2}{*}{ け } & け & へ & $x$ & \multirow{2}{*}{ ぼ } & ぼ & も & む & $x$ \\
\hline & 0 & 27 & 15 & & 1 & 22 & 6 & 13 \\
\hline \multirow{2}{*}{ せ } & せ & ح & $x$ & \multirow{2}{*}{ ぽ } & ぽ & ほ & は & $x$ \\
\hline & 7 & 15 & 20 & & 5 & 14 & 4 & 19 \\
\hline \multirow{2}{*}{$ぬ$} & $ぬ$ & む & $x$ & \multirow{2}{*}{\multicolumn{3}{|c|}{ ×不明 }} & & \\
\hline & 8 & 17 & 17 & & & & & \\
\hline
\end{tabular}

i . 「da」 $\rightarrow\lceil n a 」$, 㘣 6

症例Xの「da」の語音は， 7 名の検者全員が「na」と 誤聴している.被検者の「na」の語音は検者 7 名中 6 名 が「na」と受聴した。これをソナグラフ（図6）で見る

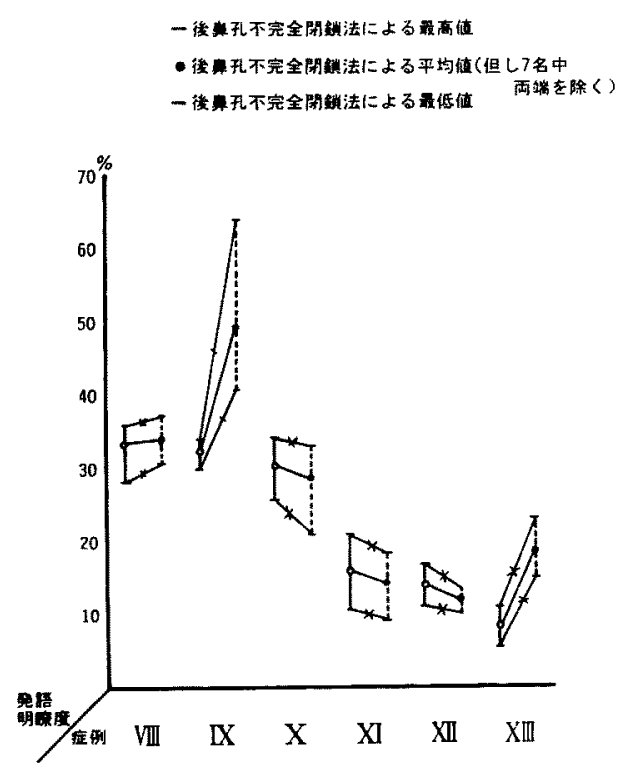

図 4 後鼻孔不完全閉鎖法による発語明瞭度

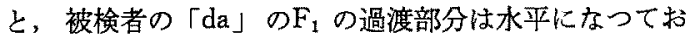
り，「na」も同様に水平になつている. 正常人の「na」は
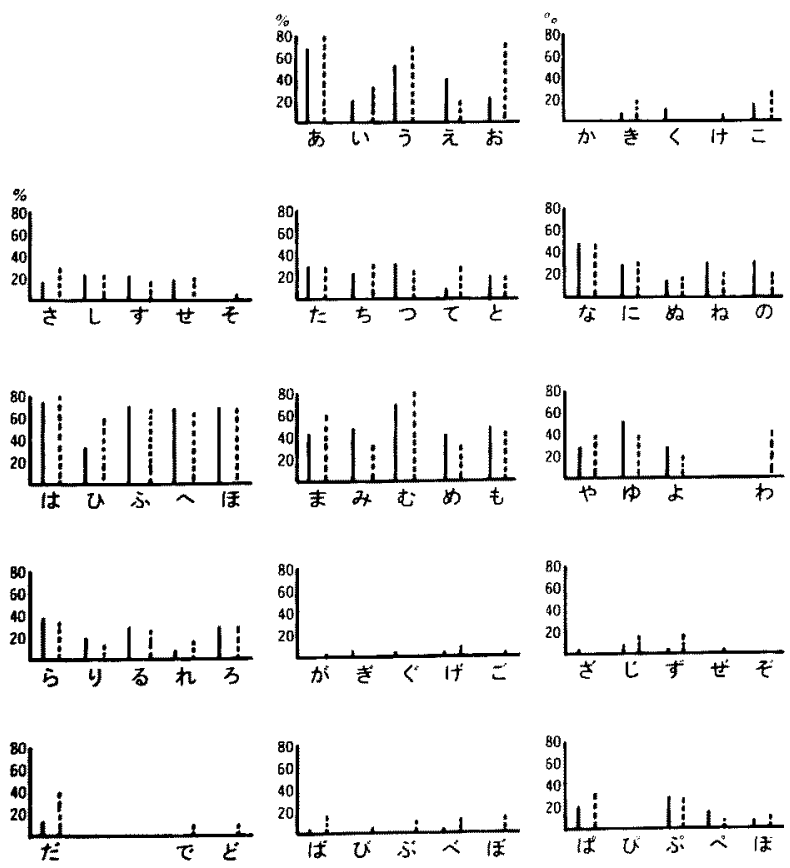

——自然の状熊

後鼻孔不完全䦥鎖法

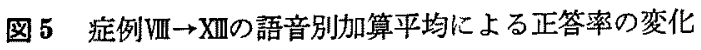



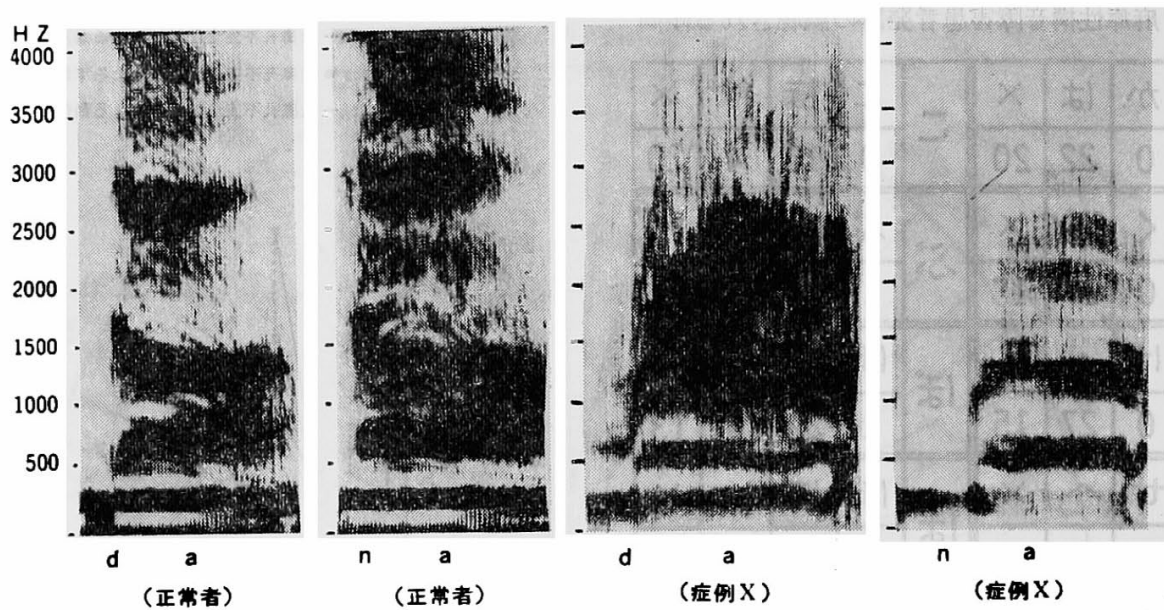

図 6 正常者および症例Xの「da」および「na」の語音のソナグラフによる比較

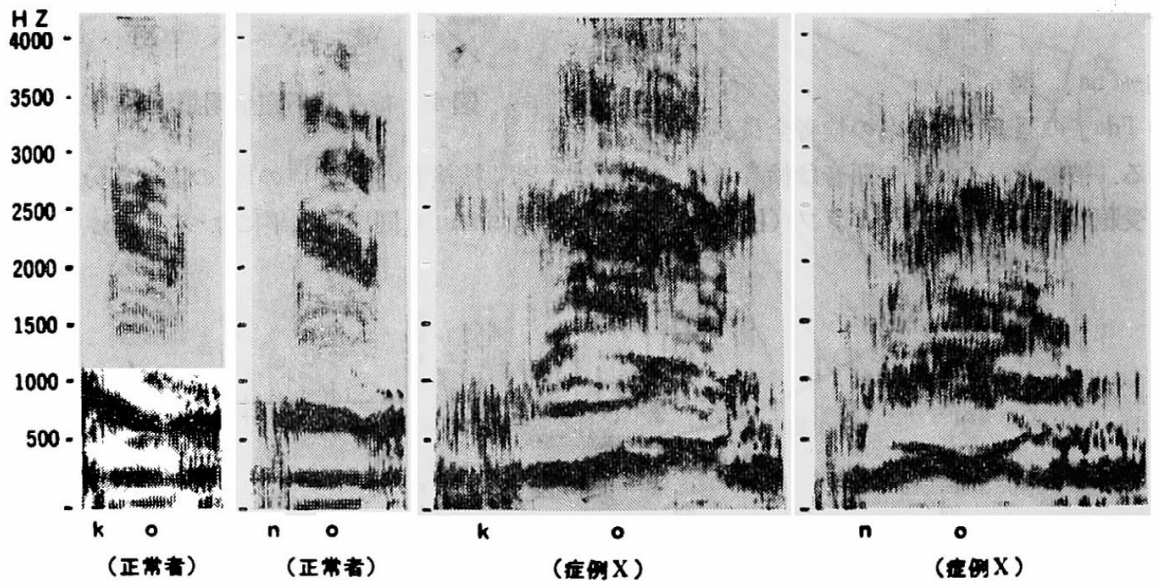

図 7 正常者および症例Xの「ko」および「no」の語音のソナグラフによる比較

これと同じであるが,「da」はこれと異り， $\mathrm{F}_{1}$ 下降， $\mathrm{F}_{2}$ は上昇している.すなわち,「da」,「na」のソナグラフ の違いは， $\mathrm{F}_{1}$ と $\mathrm{F}_{2}$ の過渡部分が重要な所見であるが， 症例Xの「 $\mathrm{da}$ 小ではそれがみられない．また後続母音の 「a」は鼻音化しているが，母音の舅音化の特徴について は, 菰口 ${ }^{3)}$ が実験的に extraresonance, antiresonance を認め高城成分のエネルギーの変動を指摘している，症 例Xでは, ソナグラフにおいて, フォルマント間成分 (extraresonance) の増強を認める。このため鼻音化して 聞えるのであろら。しかし母音は誤聴されなかつた。

ii.「ko」 $\rightarrow\lceil h o 」$, 図 7

症例Xの「ko」の語音は, 検者 7 名全員が「ho」と誤 つて聴取している. 被検者の「ho」の語音は, 検者 7 名
中 4 名が「ho」と受聴した．これをソナグラフで見ると， 被検者の「ko」の子音部分には spike fill を認めず, 被 検者の発語語音「ho」と同様に, 子音部分に摩擦音成分 を認める，正常人の「ko」の子音部分には spike fill が あり「ho」にはその子音部分に摩擦音による fill を認 める、すなわち、「ko」,「ho」のソナグラフ上の違いは 子音部分が重要な所見となる.

iii. $\lceil\mathrm{zo}\rfloor \rightarrow\lceil\mathrm{no}\rfloor$, 図 8

症例 $\mathrm{X}$ の「zo」の語音は検者 7 名中 6 名が「no」と語 聴している. 被検者の「no」の語音は検者 7 名中 5 名が

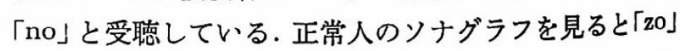
に㧧いては, 子音部分に有声摩擦音によるフォルマント の先行する fill を認め,「no」においては, その子音部 


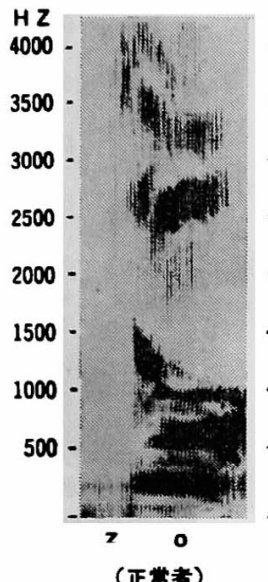

(正常者)
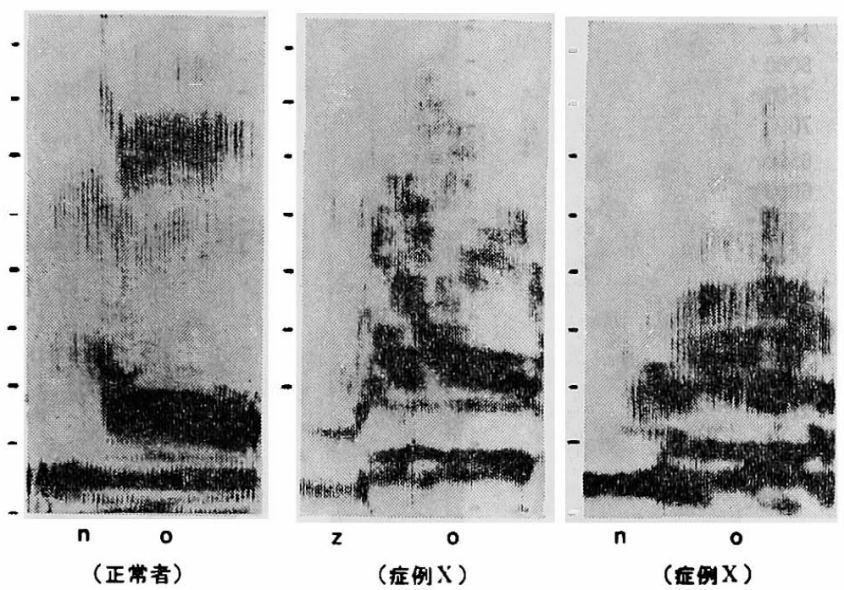

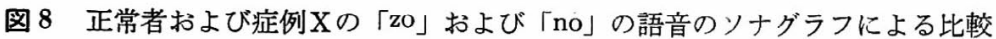

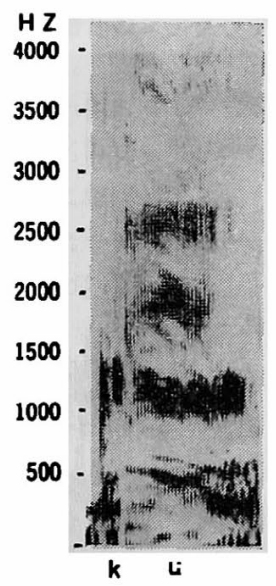

（正常者）

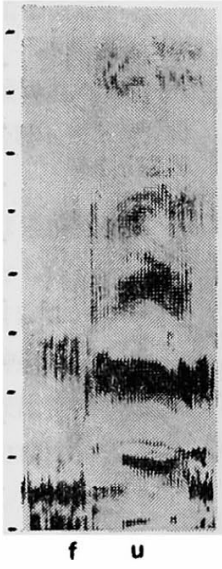

（正需者）

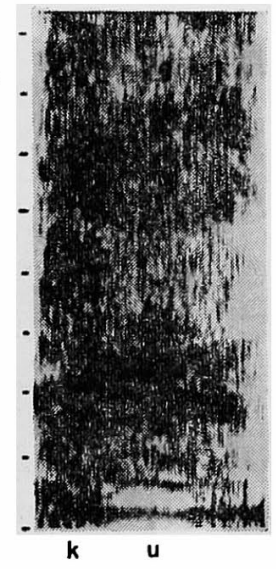

(症例V四)

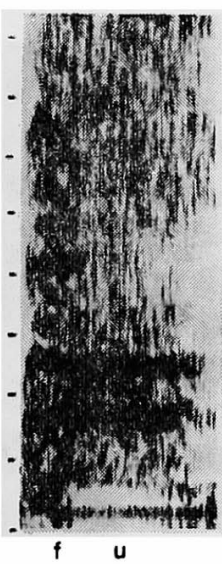

(症例四)

図 9 正常者および症例VIIの「ku」および「fu」の語音のソナグラフによる比較

分にバズ音 (nasal murmur) を認める.被検者の「zo」 の子音部分は，被検者「no」の子音部分と同様にバズ音 を認める. この所見は，被検者の発語の「no」ソナグラ フよりも，「zo」のソナグラフで著明であり，発語明膫 度榆査でも「zo」の方がはつきりと「no」と認識されて いる.

iv. $\lceil\mathrm{ku}\rfloor \rightarrow\lceil\mathrm{fu}\rfloor$. 図 9

症例䜣は, 軟口蓋および口唇の高度麻㾝と舌運動障害 がある他に，反回神経麻㾇による声門閉鎖不全がある． 嗄声のため, ソナグラフの基本ピッチが雑音様となつて いる. 本症例の $\lceil\mathrm{ku} 」$ の語音は, 検者 7 名中 5 名が $\lceil\mathrm{fu} 」$ と受聴した．被検者の「fu」の語音は，検者 7 名全員が 「fu」と受聴した．正常人のソナグラフを見ると「ku」に
はその子音部分に spike fill があり，「fu」には低い周 波数領域に摩擦音成分を認める. 被検者のソナグラフを 見ると諨聴されやすい「ku」においては，その子音部分 に spike fill を認めず, 被検者の「fu」と同様な無声子 音に特徵的な fill を認める.

v 「se $\lrcorner \rightarrow\lceil h e 」$, 図10

症例XII「se」の語音は, 検者 7 名全員が「he」と誤 聴している. 被検者の「he」の語音は 7 名中 5 名が「he」 と受聴して招り，他の 2 名は「e」と受聴している. 正常 人のソナグラフを見ると「se」では, 摩擦音のスペクト ルのエネルギーが $4000 \mathrm{~Hz}$ 以上に集中しており，「he」で は低、周波数領域に勢力が集中し，その周波数帯域の一 部が欠けた fill を認める. 被検者「se」のソナグラムは 

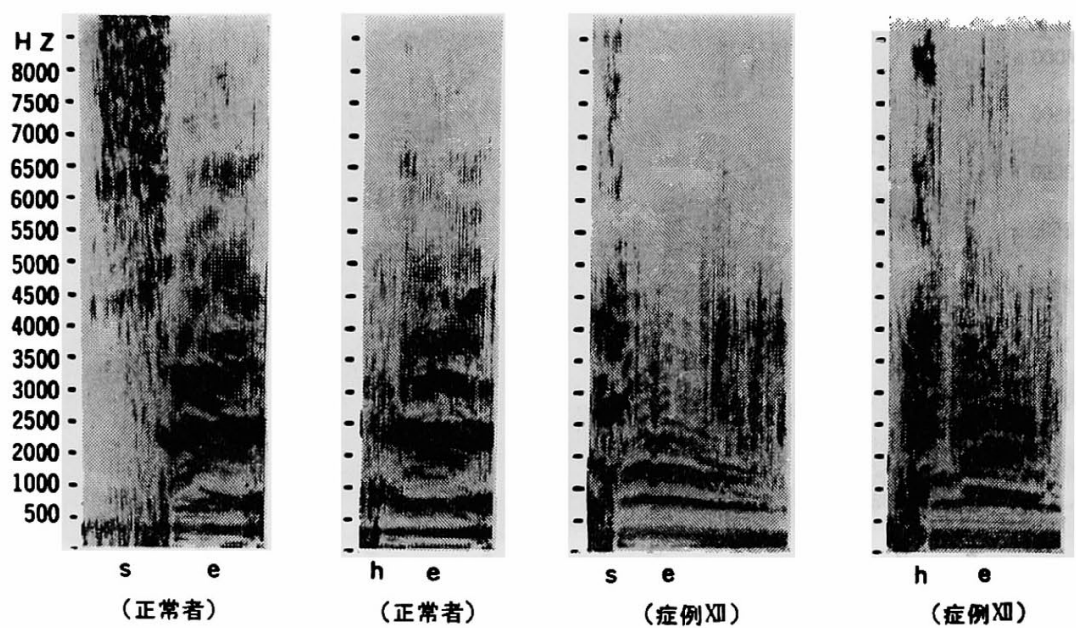

図10 正常者および症例XIIの「se」および「he」の語音のソナグラフによる比較
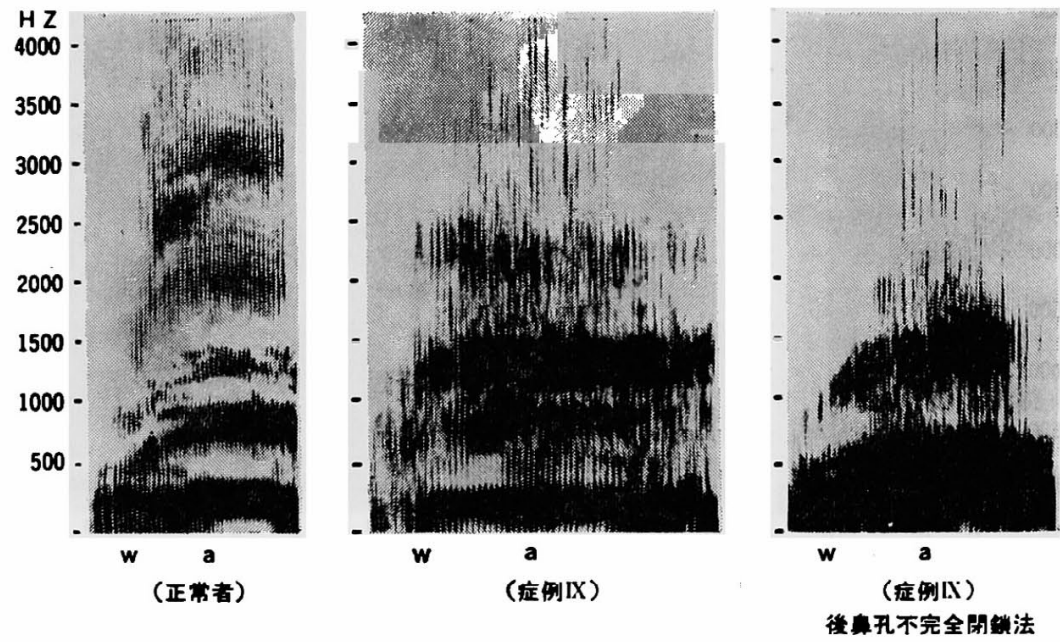

図11正常者の「wa」の語音と，症例IXの自然の状態，および後鼻孔不完全閉鎖法における「wa」 の語音のソナグラフによる比較

子音部分において高い周波数領域の fill を認めず，むし ろ低、 $4000 \mathrm{~Hz}$ 以下の周波数領域に勢力が集中し，その 周波数帯域の一部が欠けている.

D． 後鼻孔不完全閉鎖した場合の発語語音のソナグラフ vi.「wa」, 図11

正常人の「wa」のソナグラフを見ると，半母音に特徴 的なフォルマントの比較的ゆるやかな時間的変化を認め る. 症例IXの自然状態における「wa」のソナグラフを見 ると，フォルマントの洔間的変化にそしく， extraresonance の増强を認める. この症例に後鼻孔を不完全閉鎖 寸ると,「wa」のソナグラフでは, 正常人の同様なフォ
ルマントの変化を認めるようになつた，発語明瞭度検査 でも，自然の状態で「wa」は検者 7 名中 6 名が「a」と 受聴しているが，後鼻後不完全閉鎖した場合は，検者 7 名全員が「wa」と受聴している.

vii. 「te」, 図 12

正常人の「te」のソナグラフを見ると，子音部分に spike fill を認め. 症例IXの自然の状態における「te」の 語音のソナグラフを見ると，明らかな子音部分を認めな 、この症例に後鼻孔不完全閉鎖すると, 明らかな子音 部分の spike fill を認める. 発語明瞭度検査でも, 自然 の状態では,「te」は検者 7 名中 1 名が「te」と受聴し， 

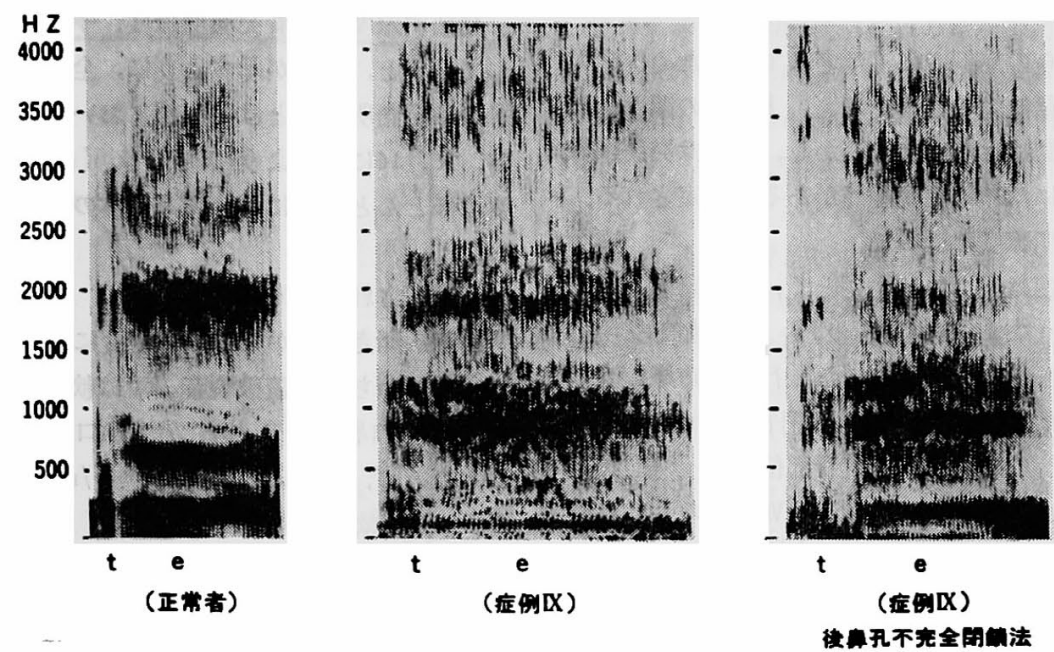

図12 正常者の「te」の語音と，症例IXの自然の状態，および後鼻孔不完全閉鎖法における「te」 の語音のソナグラフによる比較

他は「e」3 名, 不明 2 名であつたが，後鼻孔不完全閉鎖 した場合は検者 7 名中 6 名が「te」と受聴している.

\section{V. 考案ならびに総括}

麻㾇性構音障害について, Grewel') は中枢性あるいは 末梢性の神経系統の器質的障害であるとし, Allan ${ }^{53}$ は, 構音に関係ある神経筋肉系の障害と定義している. 河村 ${ }^{6)}$ は構音器官の筋群を支配している末梢神経, 神経核, 中 枢神経路の器質的障害によつて生ずる表出言語の障害を dysarthria と定義している. 広瀬”は dysarthria とは構 音障害のらち, 麻痺性構音障害は主として中枢または末 梢神経麻瘒に基つく構音器官の運動性異常によるものと し, 器質性構音障害 dysglossia（構音器官の形態的異常 に基うくもの) や，機能的構音障害 dyslalia（主として 構音器官の使い方の誤りに基づくもの, 例えば呐など） と対比しらる性格のものであるとしている.すなおち， dysarthria とは構音器官を支配する中枢性あるいは末梢 性の神経の器質的な障害に起因するものと定義できる。

麻㾝性構音障害の分顔として，1956年 Brain ${ }^{7)}$ は

1. 上部運動神経障害によるものや中枢性 構音障害 (錐体路障害)

2. 下部運動神経障害

3. 小这性構音障害

4. 錐体外路障害

に分類している. それぞれの原因によつて特徴的な臨床 所見がある，例えば，錐体路障害によるものは構音器官

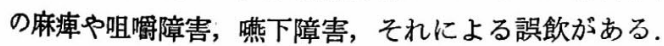

言葉はゆつくりとなり，ピッチの変化とともに鼻音化し 不明瞭なものになる。下部運動神経障害の場合, 障害さ れた神経支配下にある筇群の麻㾝, 萎縮および, 特徵の ある構音障害が起る。すなわち, 顔面神経掞よびその核 の障害により,唇音の発音困難をきたし,舌下神経または その核の障害のときには，舌運動は障害され，舌音の発 音は困難となる，小脳障害によるものは随意運動の失調 状態となり，言莱のつながりが不自然となる（scanning speech). 声のピッチも変化し, 時には爆発性に大きく なることがある. 錐体外路の障害では, 構音器官の動き の共動運動障害や不随意の動きを示す.このように，言 語障害により，それぞれの特徴的な所見がある。

著者が診た（熱海総合病院の）言語障害は，すべて脳 卒中が原因のものであり，失語症が最も多く，次いで錐 体路障害による麻瘨性構音障害であつた。本研究の研究 対象は, 麻瘦性構音障害であるが, aphasia も合併して いる 2 症例が含まれている. また,これらの症例は高齢 者が多いので, 老人性疾呆の混在しているものもいた.

<発語明瞭度について >

脳卒中後の麻痺性構音障害者の発語明瞭度を求める と, 9 83\% と広域に分散している. 表 1 から分かるご とく, 構音器官麻疸の発語能力は発語明瞭度に最も大き く関与している. 更に構音器官の中でも, 舌, 軟口蓋の 協調運動が特に大きく関与している.

発声持続時間, 連続構音回数についても検査したが, 発語能力の順位や, 発語明瞭度と関連を認めることはで 
きなかつた。

さらにこれらの症例の多くは老人であるため，老人 性痴呆による発語能力の低下を考え，IQ上の関係它調 ベたが，相関を認めなかつた。しかし，知能は発語訓練 による言語改善にはある程度関連があると推定される。

く語音別発語明膫度について〉

母音発語明瞭度は図 2 に示すごとく，他の語音よりも 良く，子音については，軟口蓋音の「か」行，歯音の「さ」 行，歯茎音のらち無声破裂音の「た」行，無声摩摖音の $/ \mathrm{s} /$ ，鼻音の「ま」行，「な」行，声門音の/h/，が良吕 つた. これを子音の発語様式と構音部位別に分類する と，表 4 となる。すなわち，症例 $\mathrm{I} \rightarrow \mathrm{VII}$ むての舌軟口㥺 協調運動が認められるものにおいては，子音のなかで発 語明膫度の良いのは無声麻撚音，鼻音，「ぱ」行を除く 無声破裂音であり，発語明膫度の悪いのは，有声破裂 音，有声摩檫音「ば」行の無声破裂音であつた。

表 4 腷卒中後の柽度扔よび中等度麻㿎性構音障害 患者の構音部位と発語様式による語音障害傾 向

\begin{tabular}{|c|c|c|c|c|c|c|c|}
\hline \multicolumn{3}{|c|}{$\operatorname{arant}^{2}$} & 兩整意 & 曹 音 & 西蕇音 & 赖口盖音 & \multirow[t]{2}{*}{ 畗阴音 } \\
\hline \multirow[b]{4}{*}{7} & \multirow{2}{*}{\begin{tabular}{|l|} 
噫 \\
音
\end{tabular}} & 無声 & $P H$ & & $\mathrm{t}$ & $k$ & \\
\hline & & 有声 & $b H$ & & $d+$ & g + & \\
\hline & \multirow{2}{*}{$\begin{array}{c}\text { 覆 } \\
\text { 普 }\end{array}$} & 無声 & & & & & \\
\hline & & 育苗 & $\mathrm{m}$ & $n \quad n$ & & $\eta$ & \\
\hline \multirow[t]{4}{*}{ 抟 } & 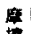 & 䍩声 & $f$ & $\mathbf{s}$ & s & & h \\
\hline & 音 & 有声 & $w+$ & $z \quad H$ & 34 & & \\
\hline & 彈 & 無声 & & & & & \\
\hline & 音 & 有象 & & & $r$ & & \\
\hline
\end{tabular}

世 著しく障害＋軽度㜔害

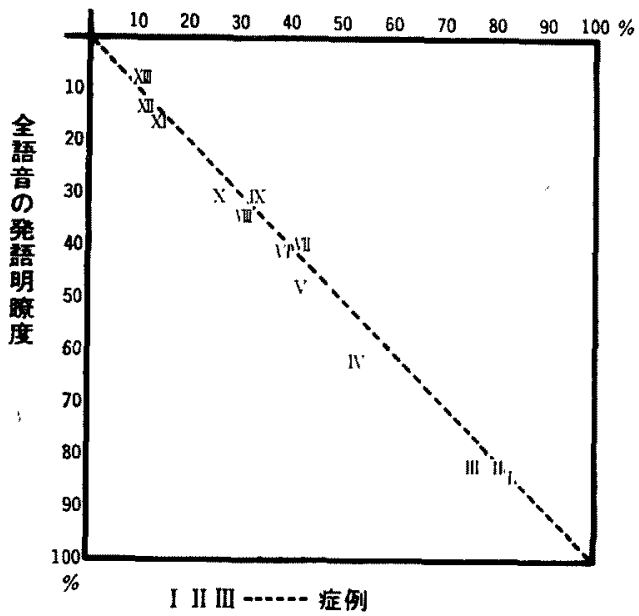

図13 子音音節の発語明裳度
発語明膫度を母音発語明瞭度，子音発語明膫度に分析 して見ると，図13が示すように，全体の発語明膫度と， 子音の登語明膫度と注各拝例において平行したが，図

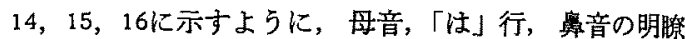
度はほとんどの例に括いて，全体の発語明瞭度より高加 つた.

〈嘼聴される傾向について〉

語音が閏きまちがえられる場合にも，一定の傾向があ る、すなわち，口蓋破裂音 $/ \mathbf{k} /$ は軟口藍麻渾により $/ \mathrm{h} /$

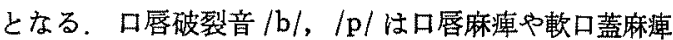
により $/ \mathrm{h} /, / \mathrm{m} /$ に変わり易い. $/ \mathrm{n} / \rightarrow / \mathrm{m} /$ は，口唇， 舌，拉よび軟口蓋麻渒により起る。 $/ \mathrm{r} /, / \mathrm{d} /, / \mathrm{z} /$ 法いず れも舌運動障害と軟口蓝麻㾝により通鼻音 $/ \mathrm{n} /$ になる。

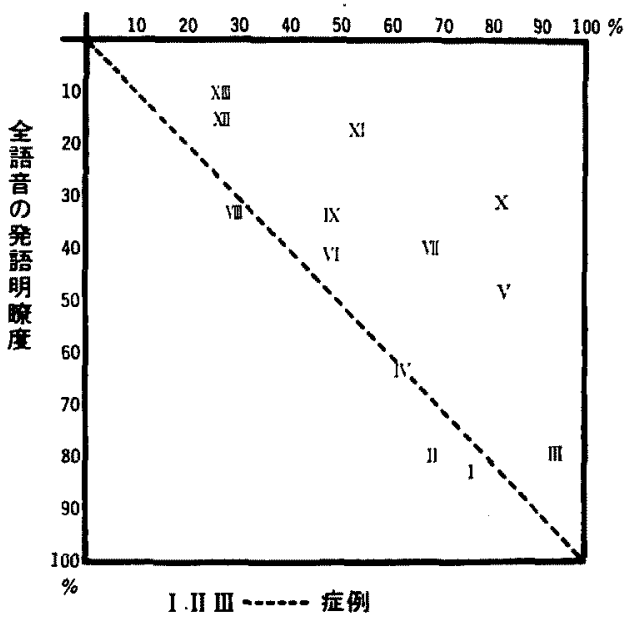

图14 母音音節の発語明膫度

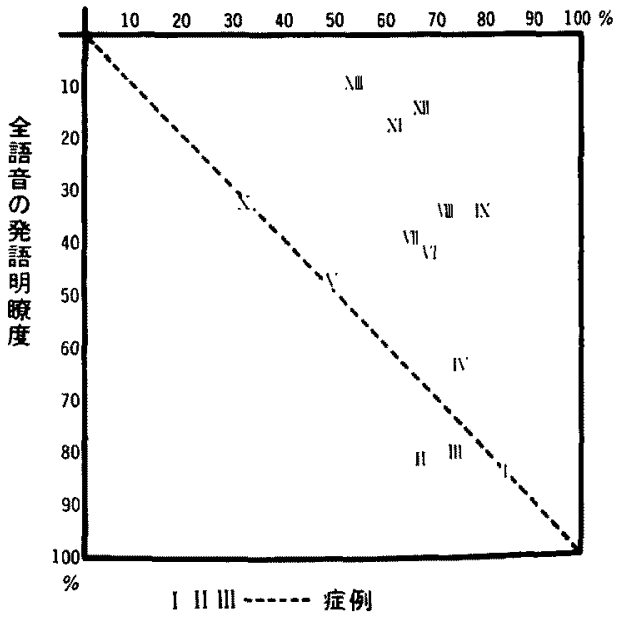

図15 注行音節発語明膫度 


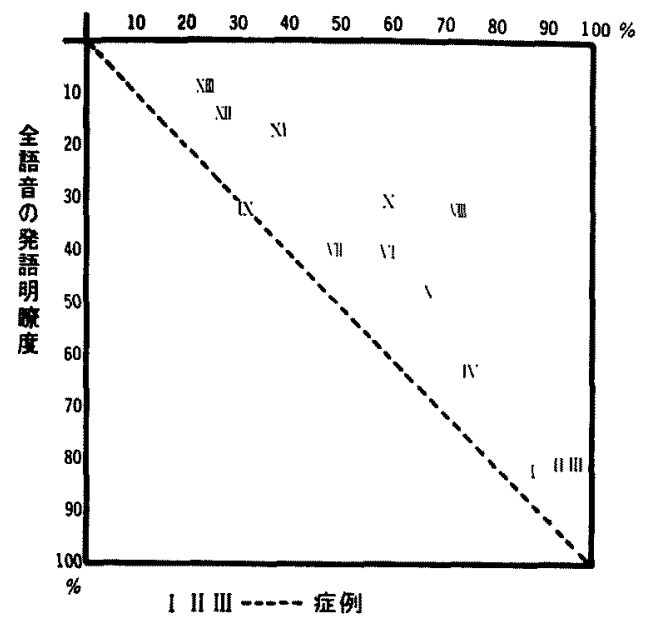

图16 鼻音音節発語明膫度

表 5 子音の誤聴傾向
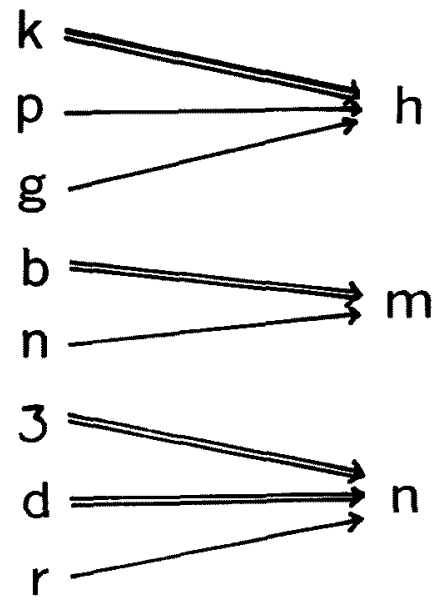

すなわち，末梢構音器官の運動不全あるいは麻渾によつ て構音が障害されるので, 脳卒中後の麻瘦性構音障害者 は誤聴され易い語音を発語する訳である。これらを総括 すると，表 5 にように，子音は $/ \mathrm{h} / \mathrm{h} / \mathrm{m} / \mathrm{l} / \mathrm{n} /$ に誤つて 㯖取される傾向が強かつた。

次に，麻瘨性構音障害において，いかなる語音が，発 語明䐲度を維持できるかについて考えて見ると，

(1)鼻腔と口腔とを開通させておかなければ発音できな 語音

(2)兽腔と口腔との遮断が不十分な場合, 音色注变化し

ているが，語音の発語明睹度が損われ難い語音 (3)各㭗音器官の迅速な協調運動を必要としない語音 などである。
通鼻音の発語明膫度が高いのは，(1)よるものであ り，母音は(2)，(3)により発語明瞭度が高く，各検查語音 の誤聴が少ないのもこのためである、「は」行音節には， $/ \mathrm{h} / \mathrm{l} / \mathrm{f} /, / \mathrm{c} /$ の三種の子音があり，この中の $/ \mathrm{h} /$ は口 腔内の気圧をほとんど高应るとなく発音され，(1)，(3) により「は」行音として聴取される，また，口唇の狭寉 ができず/f/が/h/となって，/hu/ の如く発音されて も「子」と聴取されるが，/〕/は，咽頭の狭窄を必要と し，「は」行音の中では著しく発語明瞭度が低い．

他の語音について，著しく発語明燃度の低下をきたす その要因を考劣ると，口唇と鼻腔を完全に遮断し，構音 点にかかる気圧を高めないと発音できない破裂音，摩擦 音がある。この語音を麻惲性構音障害者が発語すると， 子音が脱落して聴取されたり，誤聴されたり，いかなる 語音とも判定し難い音になつたりする。これをソナグラ フで分析して見ると，破裂子音部分特有の spike fill を 見ることができない．

麻焯性構音障害では, 明睹度が高いと考えられる通鼻 音も, 構音器官の運動障害が高度となると, 発語明膫度 が低下する，すなわち，正常の $/ \mathrm{n} /$ は上菌茎部に舌前部 が密着して発せられるのであるが，舌の運動障害が高度 になると，十分に開鎖できない，同稴に正常の $/ \mathrm{m} /$ は 口唇が密着して発せられるが，口唇の高度運動障害があ ると十分に閉鎖できなくなる。

〈後番孔不完全閉鎖について >

従来より脳卒中の麻瘨性構音障害患者の言語治療を種 ↔の方法で行つてきたが, 経過良好なものは発症後約半 年を経過すれば、ほとんど治虑し、コミュニケーション に支障をきたすことはないが，高度の言語障害のある症 例で忧，如何なる言語治療を行っても改善はなく，大き な障壁に突き当つた。これらの症例の言語治撚に際し て，外鼻孔を閉鎖すると，口唇音や破裂音が発音し易く なることをしばしば経験する。しかし外鼻孔を閉鎖する と，通嶨音の障害がおこる，そこで，鼻咽腔を狭くする だけで，完全閉鎖しなければ鼻咽腔および鼻腔の共鳴も 可能であるため開放性鼻声はある程度矯正され，表出語 音の発語明膫度が改善されるのではない加と考えた。 た語音の悬音化の程度は，上咽頭を含めた舅腔，口腔の 音響特性，および，声道から鼻腔一の開口部の面積の相 互関係によつて決定されるり そこで鼻咽腔をできるだ け狭くする目的で後鼻腔不完全䦥鎖法を用い，発語明膫 度を測定した。 その結果, 発語明膫度の上昇は 2 例のみ で，他の 4 例は不変であつた。 その原因惊，各症例によ 
り, 各構音器官の麻㾇の程度が異るためで, 怪度でも軟 口蓋の連動の認められるものでは，タンポンを利用して 適宜鼻咽腔を閍鎖したり，開放したりして発声するため 発語明瞭度が上昇するが，軟口蓋運動がほとんどないも のにとつては，タンポンは異物感となり，発声障害の一 因となる．タンポンを検查時だけ挿入し，不慣れな状態 があると十分な効果がでない場合がある，症例Vは，先 に報告したが，しばしば後鼻孔不完全閉鎖を行つて言語 訓練を行い, 発語明膫度の改善を認めた。 その後, タン ポンを行わなくても明膫度が改善されたままでいた。 えに, 後鼻孔不完全閉鋇法は麻煵性構音障害者には一応 行つてみるぶき方法であると思われる.

\section{VI. 結 論}

1 麻神性構音障害においては，発語能力と発語明膫 度, 楆音器官の麻瘒の程度とは密接な関係がある。

2. 軽度麻㾇性構音障害者に招いては, 軟口蓋音の障 害は少なく, 有声摩擦音や有声破裂音の発語障害が著し $r$.

3 構音障害程度と関係なく，母音や「は」行の発語 明膫度は高、。

4. 高度麻㾇性構音障害患者においては, 特徽的な誤 㯖語音が出現する。すなわち，子音の母音部分の誤聴は 少ないが，子音吕 $/ \mathrm{h} /, / \mathrm{m} /, / \mathrm{n} /$ 亿誤聴される傾向が強 い.

5. 誤聴語音のソナグラフによる分析結果から，破裂 子音の spike fill の消失，および母音の鼻音化比よる extraresonance や interfilling の増強が強く認められ た.
6、後番孔不完全閉鎖法により，言語治㙩によるる改善 が不能な症例に対して，発語明膫度の改善を認めた。

\section{参考文献}

1）切替一郎：新耳咽喉科学. 南山堂, 東京, 1970 .

2) 田口恒夫：言語障害治裨学。医学琵院, 東京, 1971.

3）孤口英夫：母音の奥音化炕関する実験的研究．日耳 昴, $75 ; 809-819,1972$.

4) Grewel, F.: Classification of dysarthria.: Acta Psych. Et. Neurol., 32 ; 325-337, 1957.

5) Allan, C.M.: Treatment of non fluent speech resulting from neurological disease. British J. Dis. orders of Communication. 5: Apr. 3-5, 1970.

6) 河村正三：言吾障害の臨床．p.117，金原出版，東 京, 1971 .

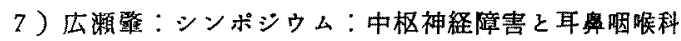

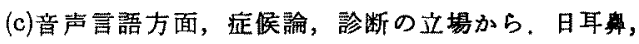
73 ; 1234-1237, 1968.

8) Brain, R.: Disease of the Nervous System.Oxford Uni. Press, 1956.

9) D. Fujimura: Spectra of nasaliyed vowels. Q.P.R., MIT. ; 214, 1960.

稿を終るに臨み御校閲を頂いた岡本教授炕澡謝すると 共に, 御協力下さつた熱海総合病院コムニケーションク リンックの各位に感謝します。

（原稿受付 炤和50.8.22日) 